\title{
Analysis of Indonesia Business Cycle through Composite Leading Indicator Data Processing for Banking Industry
}

\author{
Annisa Wahyuningsih, Riwi Sumantyo \\ Department of Economics Faculty of Economics and Business Universitas Sebelas Maret \\ Jl. Ir. Sutami No.36A Surakarta, 57126, Indonesia
}

\section{ABSTRACT}

Keywords: Composite Leading Indicator; Gross Domestic Product; Leading Indicator; Stock Price Index

JEL Classification: D51, E43, F41, G15

This study aimed to analyze business cycle of Indonesia through data processing CLI (Composite Leading Indicator) and to obtain an investment leading indicator which a composite of several indicators. This study used OECD method and used time series data, i.e. quarterly data from 2001-2013. The result of the analysis of this study was the formed CLI was well functioned (significant), although the correlation coefficient both not overlapped (low). Because IDX Composite movement was more volatile than GDP movement. However, the formed CLI was capable in following the cyclical movement of the reference series (significant). The result of hypotheses in this study was assumed that there were some variables that met the category as leading indicator in GDP reference series that were: CPI, exchange rate, property credit and housing loan. While the variables in the reference series IDX composite namely: import capital, Pi_paper, export manufacture, export agriculture, housing loan and property credit. In this study, especially for the government and central bank (Bank of Indonesia), they should be able to work together in making policies that pay attention to the economic variables classified in leading indicators.
\end{abstract}

Kata Kunci: Composite Leading Indicator; Produk Domestik Bruto; Indikator Pendahulu; Indeks Harga Saham

\begin{abstract}
ABSTRAK
Penelitian ini bertujuan untuk menganalisis siklus bisnis Indonesia melalui pengolahan data CLI (Composite Leading Indicator) dan untuk mendapatkan indicator investasi pendahulu (investment leading indicator) yang merupakan gabungan dari beberapa indikator. Penelitian ini menggunakan metode OECD dan menggunakan data time series, yaitu data kuartalan dari tahun 2001-2013. Hasil analisis dari studi ini adalah CLI yang terbentuk berfungsi baik (signifikan), meskipun korelasi koefisien keduanya relative rendah. Gerakan Indeks Harga Saham Gabungan (IHSG) lebih fluktuatif daripada gerakan PDB. Namun, CLI yang terbentuk mampu mengikuti gerakan siklus dari serial referensi dan bersifat signifikan. Dari hipotesis dalam studi ini, bahwa ada beberapa variabel yang memenuhi kategori sebagai leading indicator dalam PDB seri referensi yaitu IHK, nilai tukar, kredit properti dan perumahan. Sementara variable dalam referensi Indeks Harga Saham Gabungan (IHSG) yaitu impor modal, Pi_paper, ekspor manufaktur, ekspor pertanian, kredit properti, dan perumahan. Berdasar studi ini, khususnya bagi pemerintah dan Bank Indonesia, sebaiknya mereka saling bersinergi dalam perumusan kebijakan yang berkaitan dengan variabel-variabel ekonomi yang termasuk dalam indikator pendahulu (leading indicator).
\end{abstract}


Each country must have the goal of achieving conditions of an economy that continue to grow. Therefore, the Government issued its economic policies to boost the growth of its national output. This is due to the presence of the view that positive economic growth means an increase in welfare of society. In the theory of economic growth, the Solow growth model is known, where the model shows the output level of the economy and its growth over time is affected by the savings, population growth, and advancement of technology (engineering, process, new production methods, and new products) play a crucial role in balancing the declining returns at a time when the amount of capital increase (Mankiw, 2000).

The economic growth of a country is a reflection of the long-term increase in per capita output. The main target of economic growth is the increase of real productivity level (national income) and living standard of society (real income per capita). Each country must have a goal to achieve a growing economic conditions. This is due to the view that positive economic growth means the improvement of people's welfare. In the theory of economic growth, it is known as Solow growth model. Economic growth of countries in the world is now considered more stable than a few years earlier, judging by its less volatile real GDP. Especially since many countries in the world today are starting to issue policies for developing the progress of the country, embracing the framework of inflation targeting, and increasing the independence of the central bank in running its functions. Volatility is negatively related to bank lending and positively related to trade flow (Cecchetti, Alfonso, \& Krause, 2006).

The definition of business cycle as cited in the economic dictionary is as a fluctuation of the level of economic activity (real GDP) that alternates between the depression and the period of prosperity (boom). There are 4 stages in the economic cycle. Each cycle has 2 types of turning points, i.e., the peak and the trough. These 2 turning points indicate a signal if the direction of an indicator cyclical movement changes from the period of expansion to the contraction period or otherwise. These 2 turning points can only be determined using time series data which are the deviation of the trend, which is also the definition of the business cycle used in this study. It can be concluded that this stage will come and go all the time in a country's economy.

Business Cycle Indicators (BCI) is one of the common indicators used to predict future economic conditions or economic trends. For example, the social and economic statistics are published by various sources like government departments. These indicators are leading indicator, coincident indicator, and lagging indicator.

One alternative theory is that the primary cause of economic cycles is due to the credit cycle, the net expansion of credit (increase in private credit, equivalently debt, as a percentage of GDP) yields economic expansions, while the net contraction causes recessions, and if it persists, depressions. In particular, the bursting of speculative bubbles is seen as the proximate cause of depressions, and this theory places finance and banks at the center of the business cycle.

A primary theory in this vein is the debt deflation theory of Irving Fisher, which he proposed to explain the Great Depression. A more recent complementary theory is the Financial Instability Hypotheses of Hyman Minsky, and the credit theory of economic cycles is often associated with Post-Keynesian economics such as Steve Keen.

Post-Keynesian economist Hyman Minsky has proposed an explanation of cycles founded on fluctuations in credit, interest rates, and financial frailty, called the Financial Instability Hypotheses. In an expansion period, interest rates are low and companies easily borrow money from banks to invest. Banks are not reluctant to grant those loans, 
because expanding economic activity allows business increasing cash flows and therefore they will be able to easily pay back the loans. This process leads to firms becoming excessively indebted, so that they stop investing, and the economy goes into recession.

According from some aspects of previous studies, it is found that the several studies of the Business Cycle of a country have been done by several researchers. Those studies are based on Keynessian Theory and Monetaryist Theory. Business Cycle studies are conducted internationally and domestically. The researchers who have studied Business Cycle are Kibritcioglu, Kose, \& Ugur (1999), Zhang \& Zhuang (2002), Kusuma, Surjaningsih, \& Siswanto (2004), Nilsson \& Brunet (2005), Setiana (2006), and Macroeconomic Indicator Development Study from Bank Indonesia (2011).

Most of those studies use the HP Filter Method to process trend estimates like Zhang \& Zhuang (2002) which make IPI (Index of Industrial Production) for Malaysia and MPI (Index of Manufacturing Production) for Philippines and produce composite consisting of 6 leading indicators for each country. The next researcher, Nilsson \& Brunet (2005) found 5 indicators that could be categorized as CLI (Composite Leading Indicator) and affect the Business Cycle.

Babecký et al. (2012) concluded that onsets of banking and currency crises tend to be preceded by booms in economic activity. In particular, we find that growth of domestic private credit, increasing FDI inflows, rising money market rates as well as increasing world GDP, and inflation were common leading indicators of banking crisis. Currency crisis onsets were typically preceded by rising money market rates, but also by worsening government balances and falling central bank reserves. Early warning indicators of debt crisis are difficult to uncover due to the low occurrence of such episodes in our dataset. Finally, employing a signaling approach we show that using a composite early warning index increases the usefulness of the model when compared to using the best single indicator (domestic private credit).

Barrel et al. (2010) estimated logit crisis models for OECD countries, finding strong effects from capital adequacy and liquidity ratios as well as property prices, and can exclude traditional variables. Higher capital adequacy and liquidity ratios have a marked effect on the crisis probabilities, implying long-run benefits to offset some of the costs that such regulations may bank regulation, property prices, and early warning systems for banking crises in OECD Countries.

Borio \& Lowe (2002) stated that it is possible to construct simple composite indicators of banking crises that can be useful in assessing the risk of future financial distress with a reasonable degree of confidence. Obviously, such indicators of financial imbalances should at best be used as one element in a more thorough assessment of vulnerabilities and never as substitutes for it.

Bussiere \& Fratzscher (2006) showed that applying a multinomial logit model, which allows distinguishing between more than 2 states, is a valid way of solving this problem and constitutes a substantial improvement in the ability to forecast financial crises. The empirical results reveal that, for a set of 32 open emerging markets from 1993 till the present, the model would have correctly predicted a large majority of crises in emerging markets.

Ciccarelli, Maddaloni, \& Peydro (2010) concluded that the credit channel amplifies a monetary policy shock on GDP and prices through the balance-sheets of households, firms, and banks. For corporate loans, amplification is highest through the bank lending and the borrower's balance sheet channel, for households, demand is the strongest channel.

Crespo-Cuaresma \& Slacik (2009) concluded that if the crisis index identifies a crisis period (de- 


\section{Jurnal Keuangan dan Perbankan | PERBANKAN}

Vol. 21, No. 4, Oktober 2017: 659-669

fined as the period up to a year before a crisis) instead of a crisis occurrence. In this setting, the extent of real exchange rate misalignment and financial market indicators appear as robust determinants of crisis periods.

Demirgüç-Kunt \& Detragiache (1998) examines the determinants banking crises in developing and developed countries. The result are crises tend to erupt when the macroeconomics environment is weak particularly when growth us low and inflation is high. Also, high real interest rate are clearly associated with systemic banking sector problems and there is some evidence that vulnerability to balance of payment crises has played role. Countries with an explicit deposit insurance scheme were particularly at risk, as weak countries with weak law enforcement.

Demirgüç-Kunt \& Detragiache (2005) reviews the 2 basic methodologies adopted in crosscountry empirical studies - the signals approach and the multivariate probability model - and their application to studying the determinants of banking crises. The use of these models to provide early warnings for crises is also reviewed, as are studies of the economic effects of banking crises and of the policies to forestall them.

Dell'Ariccia, Detragiache, \& Rajan (2008) concluded that differential effects are stronger in developing countries, in countries with less access to foreign finance, and where banking crises are more severe and find that blanket guarantees and regulatory forbearance work best in limiting the effect of banking crises on real activity

Frankel \& Rose (1996) concluded that crashes tend to occur when output growth is low, the growth of domestic credit is high, and the level of foreign interest rates are high. A low ratio of FDI to debt is consistently associated with a high likelihood of a crash.

Frankel \& Saravelos (2012) concluded that central bank reserves and past movements in the real exchange rate were the 2 leading indicators that had proven the most useful in explaining crisis incidence across different countries and episodes in the past. For the 2008-2009 crisis, we use 6 different variables to measure crisis incidence, drops in GDP and industrial production, currency depreciation, stock market performance, reserve losses, and participation in an IMF program. We find that the level of reserves in 2007 appears as a consistent and statistically significant leading indicator of who got hit by the 2008-2009 crisis, in line with the conclusions of the pre-2008 literature. In addition to reserves, recent real appreciation is a statistically significant predictor of devaluation and of a measure of exchange market pressure during the current crisis.

Kaminsky \& Reinhart (1999) concluded that problems in the banking sector typically precede a currency crisis-the currency crisis deepened the banking crisis, activating a vicious spiral, financial liberalization often precedes banking crises.

Levy-Yeyati \& Panizza (2011) indicates that default episodes mark the beginning of the economic recovery and that the negative effects of a default on output are likely to be driven by the anticipation of default, independently of whether or not the country ultimately decides to validate it.

Mody \& Sandri (2012) concluded that eligibility for the Euro in 1999 had been approved despite known weaknesses in public accounting practices. The sharp drop in the public finances was due in all 3 countries to the downturn in the 'real' economy associated with job losses and falling tax returns, but it was amplified by the transmission of risk and liability from the banking sector to the sovereign

Reinhart \& Rogoff (2011) concluded that first, external debt surges are an antecedent to banking crisis. Second, banking crises (domestic and those in financial centers) often precede or accompany sovereign debt crisis, they find they help predict them. Third, public borrowing surges ahead of external sovereign default, as govern- 
ments have "hidden domestic debts" that exceed the better documented levels of external debt.

Furthermore, some researchers who use the GDP as the reference series of BPS (2003) found 6 turning points of the Indonesia business cycle during January 1985-December 2003. Setiana (2006) found 9 variables that became leading indicators. Researcher named Kibritcioglu, Kose, \& Ugur (1999) found 51 indicators categorized as leading indicators with the Turkish State Case Study. The Development Study of Macroeconomic Indicators from Bank of Indonesia (2011) found nominal interest rates as leading indicator categories. The last researcher is Kusuma, Surjaningsih, \& Siswanto (2004) which estimated investment movements in the range of 1.4-4.6 months ahead.

There are several factors affecting the rise or fall of GDP economic growth, which are: (1) land and other natural resources; (2) number and the quality of population and labor; and (3) capital goods and technological level. As for IDX Composite, the factors are: (1) the desire to have a large cash money; (2) panic factor; (3) macro fundamental; and (4) company fundamental.

\section{METHOD}

In this study, the data analysis technique is done by using CLI analysis method to process and discuss the data that have been obtained and to test the applied hypotheses. In this study, the variables used are dependent variable (variable $Y$ ) that is GDP and IDX composite. Independent variable ( $\mathrm{X}$ variable), i.e., IPI, crude oil, CPI, exchange rate, import capital, Pi_paper, car sales, barrels exports, manufacturing exports, agricultural exports, housing loans, property credits, and electricity consumption. The first dependent variable is GDP (Gross Domestic Product) with constant price. This constant variable of GDP is used as the reference series in this study. Where GDP (billion Rupiah) is the overall value of all goods and services produced within the territory in a certain period of time (usually per year). The second dependent variable used as the reference series in this study is IDX composite (stock price index in million Rupiah). Where the stock is a product of the capital market. Shares represent equity participation in the ownership of a limited liability company or commonly called the issuer. In determining the leading indicator, the first thing to do is to determine the reference series whether it is classified as single series or multiple series. Next, determine the turning point of the reference series which at this stage must estimate the trend variable and determine the peak and valley. The last is determining the category of CLI formers to count how many macroeconomic variables are included in the leading indicator category.

\section{RESULTS}

The Indonesia economy shows a better and more stable performance during 2003 as reflected in the increasing of economic growth. Nevertheless, the economic growth is still not sufficient to absorb additional labor so that the number of unemployment is still increasing. World trade activity is still sluggish resulting in low growth of Indonesia export volume, especially non-oil commodities.

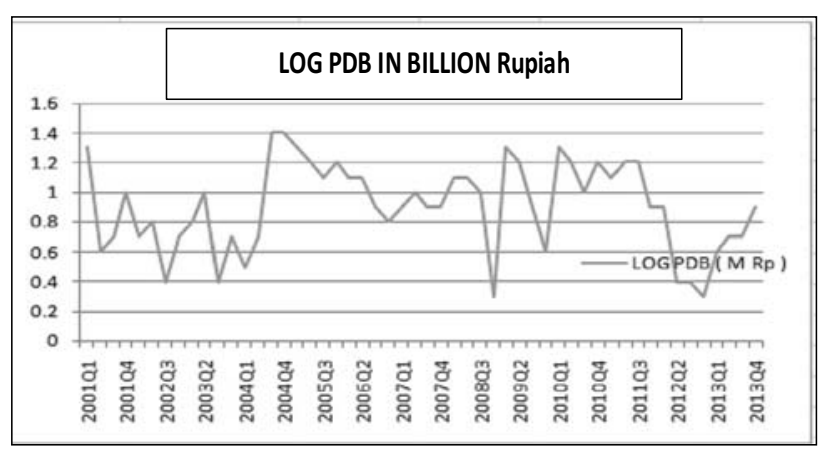

Figure 1. Graph of GDP LOG

Source: The processed log GDP data

According to the graph in Figure 1, it can be seen that by the end of 2003, the economic growth 
began to increase again despite not achieving its original growth. However, after the end of 2004, Indonesia's growth increased rapidly, which indicates that Indonesia has been detached from the impact of the monetary crisis a few years ago. The GDP graph in the form of logarithm shows the seasonal adjusted fluctuations. This seasonal fluctuation indicates that generally in economic activity there is a tendency to strengthen in the fourth quarter and be compensated by a decrease during the first quarter of a calendar year.

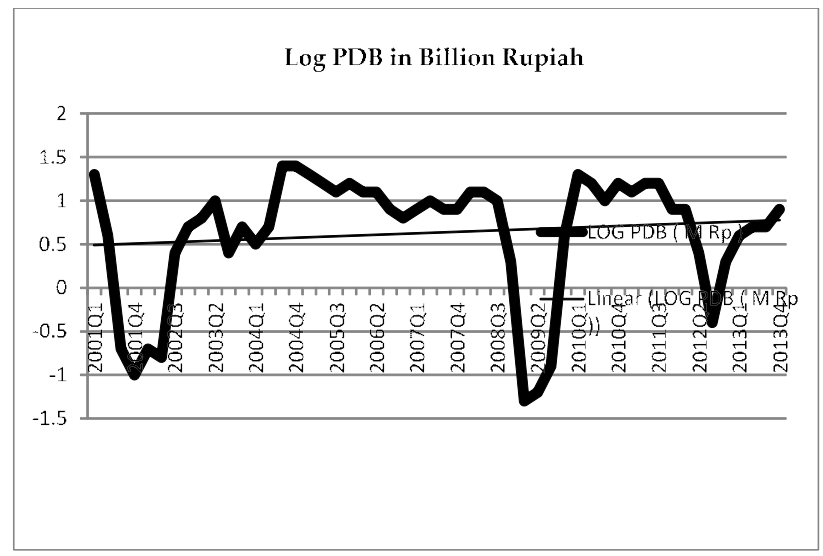

Figure 2. Graph of GDP Trend

Source: The processed GDP trend data

The GDP trend graph in Figure 2 is a plot of the GDP trend and cyclical GDP. This graph plot is obtained from the regression method of HP filter which estimates the trend and then separated from the cyclical element. The GDP trend shows that the Indonesia economy over the past 13 years has undergone 3 phases, which are experiencing a phase increase from the second quarter of 2003 to the fourth quarter of 2004, then experiencing a slowing phase from the first quarter of 2005 to 2008 third quarter. If only the government could observe the slowdown phase that began in 2005, then actually the government can have a policy evaluation to avoid worse conditions.

In 2009 and in the second quarter of 2013 there is a decrease in economic growth. This is due to a decrease in the percentage of goods and services from some formal sectors which also states that there is a decrease in income in some sectors. In addition, this is due to the unstable world economy because some changes in the structure of economic policy in developed and developing countries with the re-allocation of new resources for the production process.

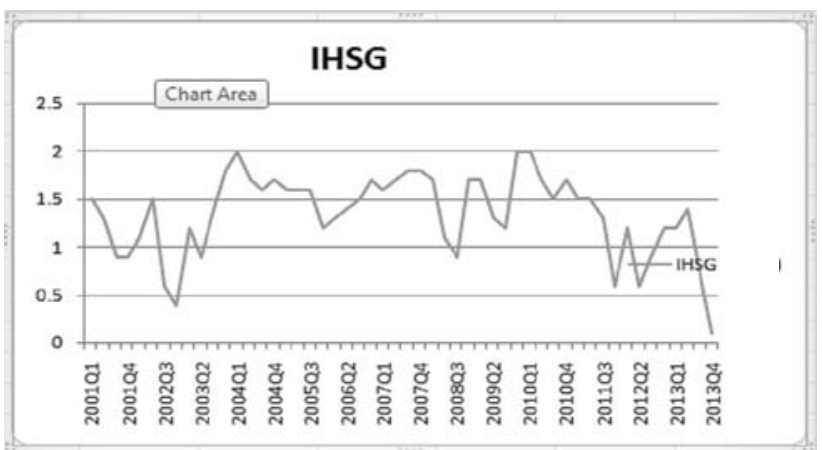

Figure 3. IDX Composite Log Graph Source: The processed IDX composite log data

Similar to the graph of GDP shown earlier, the IDX composite graph in the form of logarithm also shows the existence of seasonal elements, so that it is given the same treatment with GDP and all the econometric variables analyzed in this study, which is omitted with X-12 program in software E-views. Similar with the pattern of GDP movement, IDX composite movement patterns tend to increase in the first quarter of 2004, and then gets slowdown but not static like in the trend of GDP which is quite flat, IDX composite trend has increased although not as big as the original growth.

The IDX composite graph shows the presence of seasonal elements. IDX composite movement patterns tend to increase in the first quarter of 2004, and then decelerate but not static as well as in the trend of GDP which is quite flat, IDX composite trend has increased although not as big as the original growth. 
Analysis of Indonesia Business Cycle through Composite Leading Indicator Data Processing for Banking Industry Annisa Wahyuningsih, Riwi Sumantyo

Table 1. Comparison of Variable Fluctuation Patterns on GDP Reference Series

\begin{tabular}{|c|c|c|c|c|c|c|c|c|}
\hline Indicator & PDB & IPI & IHSG & Crude Oil & CPI & $\begin{array}{c}\text { Exchange } \\
\text { Rate }\end{array}$ & $\begin{array}{l}\text { Import } \\
\text { Capital } \\
\end{array}$ & Pi_Paper \\
\hline$\overline{\mathrm{SD}}$ & 9.2229 & 4.532819 & 31.9379 & 32.52066742 & 3.662735 & 11.77259466 & 27,7158157 & 18.50905608 \\
\hline Average $X$ & 7.0585 & 93.64316 & 23.5443 & 16.1884 & 7.8711 & 2.4008 & 10.1325 & 2,7136 \\
\hline Volatile (\%) & $131 \%$ & $5 \%$ & $136 \%$ & $201 \%$ & $47 \%$ & $490 \%$ & $274 \%$ & $686 \%$ \\
\hline $\begin{array}{l}\text { Volatile } \\
\text { Catagori }\end{array}$ & High & Low & High & High & Low & High & High & High \\
\hline Indicator & Pi_Paper & Car Sales & Coal Export & $\begin{array}{c}\text { Manufacture } \\
\text { Export }\end{array}$ & $\begin{array}{c}\text { Agri } \\
\text { Export }\end{array}$ & $\begin{array}{c}\text { Housing } \\
\text { Loan }\end{array}$ & $\begin{array}{c}\text { Property } \\
\text { Credit } \\
\end{array}$ & $\begin{array}{l}\text { Electricity } \\
\text { Consump }\end{array}$ \\
\hline$\overline{\mathrm{SD}}$ & 3.60905608 & 18.9070588 & 25.00967 & 11.64966464 & 18.55610184 & 9.647699578 & 10.34030765 & 3.034984523 \\
\hline Aver & 2.7136 & 22.6081 & 19.8546 & 4.9723 & 3.3628 & 25.7355 & 24.5398 & 7.0369 \\
\hline Volatile (\%) & $668 \%$ & $128 \%$ & $126 \%$ & $234 \%$ & $552 \%$ & $37 \%$ & $42 \%$ & $44 \%$ \\
\hline $\begin{array}{l}\text { Volatile } \\
\text { Category }\end{array}$ & High & High & High & High & High & Low & Low & Low \\
\hline
\end{tabular}

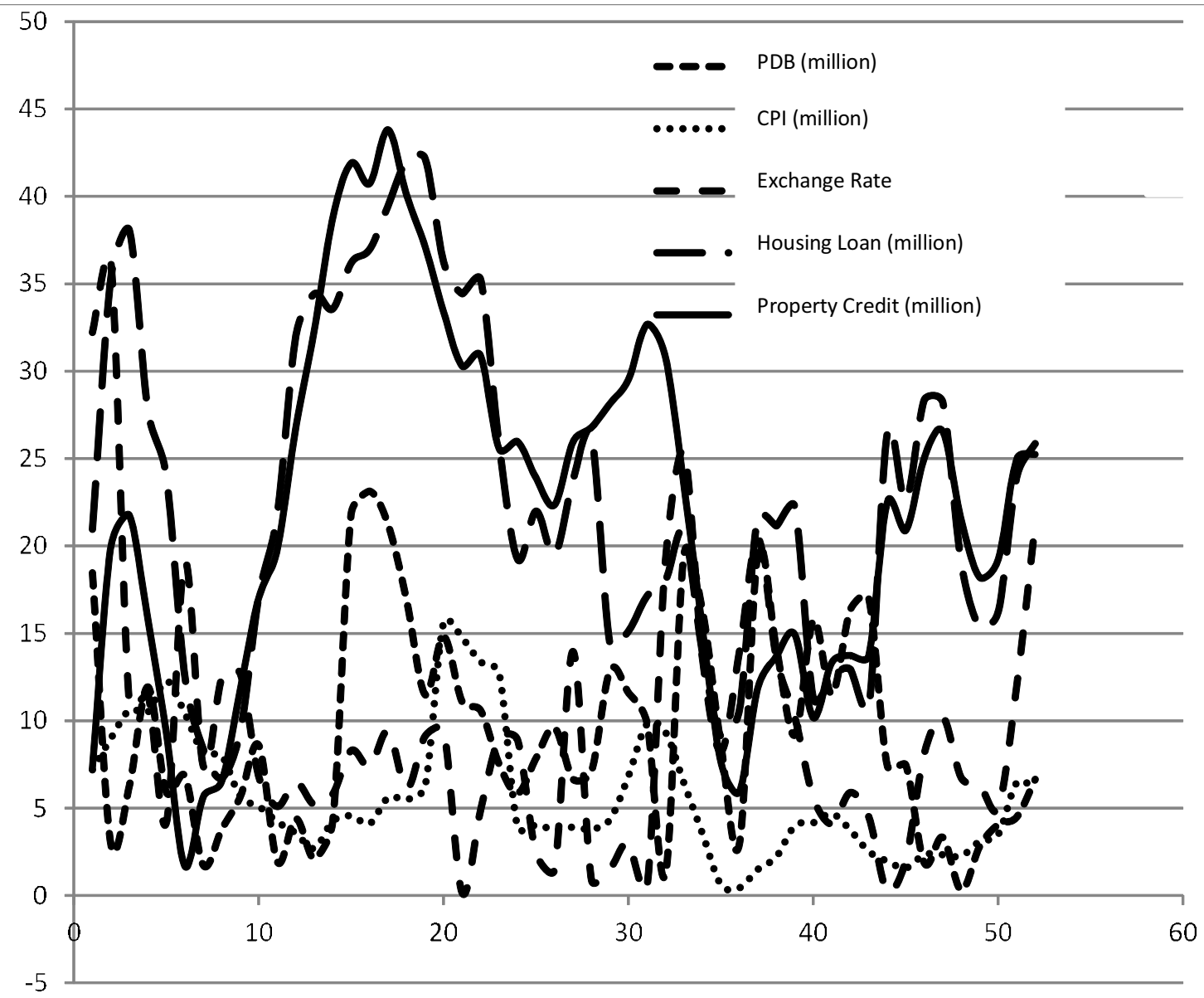

Figure 4. Graphics Forming the CLI Component for GDP Reference Series 
In the first quarter of 2010, IDX composite experienced a bullish trend and in the second quarter, IDX composite set a record again. This upward trend is due to the presence of foreign funds coming into the domestic capital market but there was a decrease in cyclical movements in 2008.

During the study period from 2000 first quarter to the fourth quarter of 2013, the result of the 2 expansion periods is expressed as, the first expansion period occurred in the fourth quarter of 2001 until the second quarter of 2002. Further contraction occurs in the third quarter of 2002.

Variables that belong to high volatile category because they have value above 100 percent. Variables that belong to the low volatile category because they have a value below 50 percent. If we want to see the category of macroeconomic variables whether it is included in leading, coincident or lagging, the first thing to observe is looking at the results of the correlogram. If there is a lead/ lag on the second (2) has a large value, this indicates that the variable is included in the leading category. Furthermore, if there is a lead/ lag at zero (0) has a large value, this indicates that the variable is included in the coincident category. Furthermore, if there is a lead/ lag at the first point (1) has a large value, it indicates that the variable belongs to the lagging category.

It can be seen from the Figure 4 that the leading indicator is the economic variables such as CPI, exchange rate, property credit, and housing loan. The average variable indicates a quarterly lead time of 0.75 in the GDP reference series with a correlation coefficient of 0.43 . Coefficients with a correlation of 0.43 indicate a moderate variable.

Figure 5 show that the leading indicator is the economic variables such as capital import, PI_paper, export manufacture, export agriculture, housing loan, and property credit. The average variable shows the lead time 2 quarter of the se-

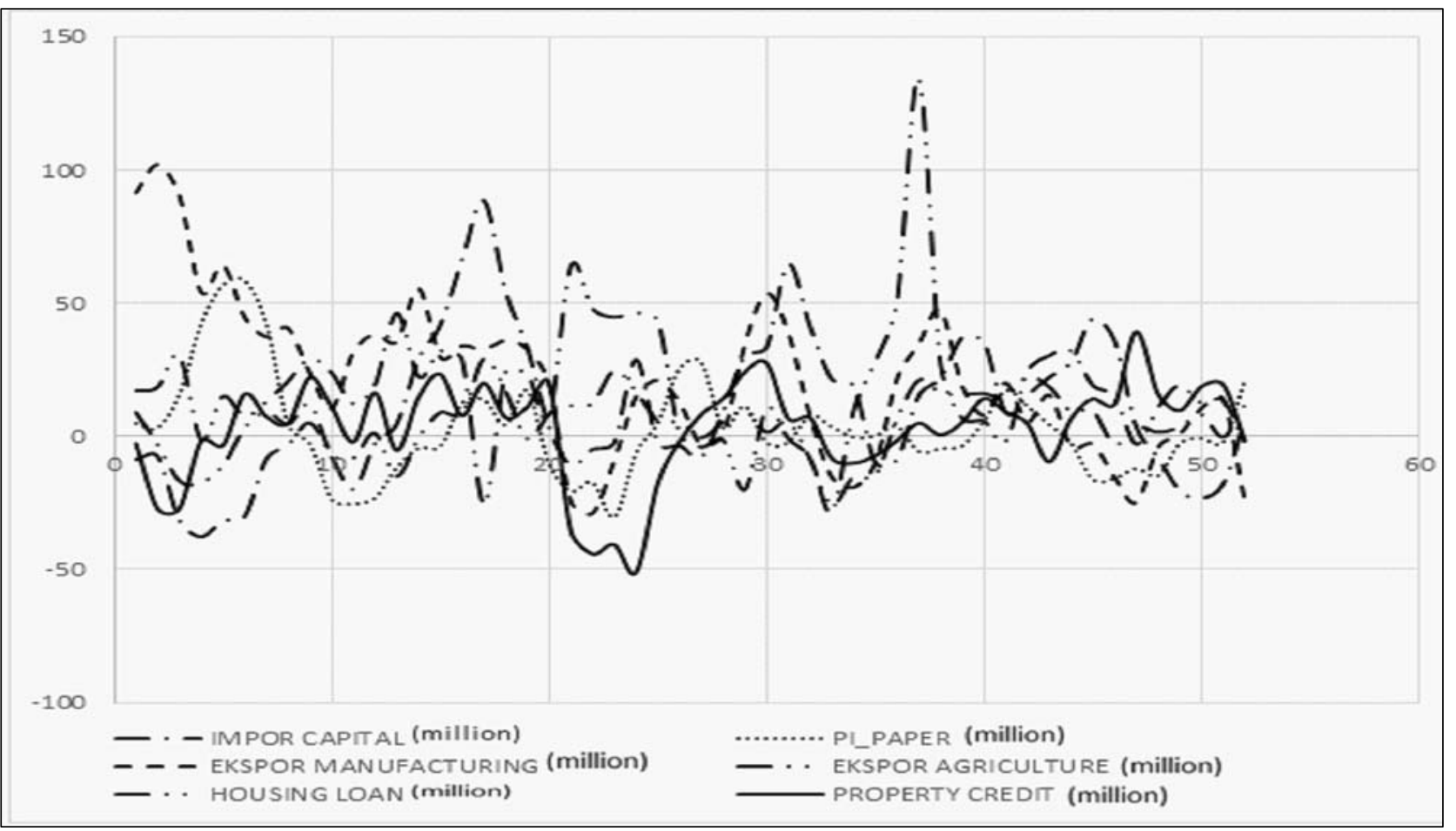

Figure 5. Graphics Forming the CLI Components for the IDX Composite Reference Series 
ries GDP reference with correlation coefficient 0.39 . Coefficient with correlation of 0.39 indicates weak variable. If the weak economic growth leads to lower demand for goods and services, thus it will reduce corporate earnings. It is not similar with Frankel \& Saravelos (2012), they concluded that central bank reserves and past movements in the real exchange rate were the 2 leading indicators that had proven the most useful in explaining crisis incidence across different countries and episodes in the past. For the 2008-2009 crisis, we use 6 different variables to measure crisis incidence, drops in GDP and industrial production, currency depreciation, stock market performance, reserve losses, and participation in an IMF program. We find that the level of reserves in 2007 appears as a consistent and statistically significant leading indicator of who got hit by the 2008-2009 crisis, in line with the conclusions of the pre-2008 literature. In addition to reserves, recent real appreciation is a statistically significant predictor of devaluation and of a measure of exchange market pressure during the current crisis.

\section{DISCUSSION}

As explained earlier, the CLI is formed by a collection of leading indicators are expected to predict the movement of the Indonesia economy proxy of GDP and JCI. Therefore the results of leading indicators are slightly different to the reference series of GDP and JCI, it will be created for the CLI then compared the results.

The leading indicator forming the CLI Component for GDP is the economic variables such as $\mathrm{CPI}$, exchange rate, property credit, and housing loan. The leading indicator forming the CLI Components for the IDX Composite is the economic variables such as capital import, PI_paper, export manufacture, export agriculture, housing loan, and property credit. That support examines Nilsson \& Brunet (2005) found 5 indicators that could be categorized as CLI and affect the Business Cycle.
It is not similar with Frankel \& Saravelos (2012) for the 2008-2009 crisis, with 6 different variables to measure crisis incidence, drops in GDP and industrial production, currency depreciation, stock market performance, reserve losses, and participation in an IMF program. In addition to reserves, recent real appreciation is a statistically significant predictor of devaluation and of a measure of exchange market pressure during the current crisis. Kaminsky \& Reinhart (1999) concluded that problems in the banking sector typically precede a currency crisis-the currency crisis deepened the banking crisis, activating a vicious spiral, financial liberalization often precedes banking crises. Mody \& Sandri (2012) showed the sharp drop in the public finances was due in all 3 countries to the downturn in the 'real' economy associated with job losses and falling tax returns, but it was amplified by the transmission of risk and liability from the banking sector to the sovereign.

From the result, this research can provide an overview of the business cycle volatility in Indonesia during the last 13 years with the use of 2 series of reference. For the series of GDP reference, there are variables that belong into the category of leading indicators like economic variables such as CPI, exchange rate, property credit, and housing loan. As for the reference series IDX composite there are variables that belong into the category of leading indicator namely capital import variables, PI_paper, export manufacture, export agriculture, housing loan, and property credit. Both government and private institutions are expected to continue working with government and private institutions or universities in Indonesia.

\section{CONCLUSION AND SUGGESTIONS}

\section{Conclusion}

From the analysis results above, it can be concluded that for the series of GDP reference, there are variables that belong into the category of leading indicators like economic variables such 


\section{Jurnal Keuangan dan Perbankan | PERBANKAN}

Vol. 21, No. 4, Oktober 2017: 659- 669

as CPI, exchange rate, property credit, and housing loan. As for the reference series IDX composite there are variables that belong into the category of leading indicator namely capital import variables, PI_paper, export manufacture, export agriculture, housing loan, and property credit. Both government and private institutions are expected to continue working with government and private institutions or universities in Indonesia.

For the data provider, it is expected to improve its statistical system, so that the data can be available with long time series, and high frequency. It also can start providing statistic data that is very potential to be leading indicator according to similar international studies. The government as fiscal authority and Bank of Indonesia as the monetary authority are expected to cooperate to make policies that put a concern to the variables classified in the leading. Like responding to escalation conditions of global economic uncertainty risks that have begun to manifest its impact into the national economy indicated by the emergence of deficit balance of the State Budget (APBN) and trade balance deficit in order to keep the growth of economic in stable condition.

\section{Suggestions}

The government as a fiscal and Bank of Indonesia as the monetary authorities to work together to create a policy that pays attention to variables which belong to the leading. Like to respond to the conditions of the global economy uncertainty risk of escalation which has already started to manifest their impact into the national economy which is indicated by the appearance of a deficit balance budget revenue and expenditure of the State and the deficit the trade balance in order to remain capable of walking happy keeping the momentum of growth that had started to manifest.

\section{REFERENCES}

Babecký, J., Havránek, T., Matijù, J., Rusnák, M., Šmídková, K., \& Vašíèek, B. (2012). Banking, debt, and currency crises: Early warning indicators for developed countries. Working Paper Series, 1485, 1-45.

Barrell, R., Davis, E. P., Karim, D., \& Liadze, I. (2010). Bank regulation, property prices, and early warning systems for banking crises in OECD countries. Journal of Banking \& Finance, 34(9), 2255-2264.

Borio, C., \& Lowe, P. (2002). Assessing the risk of banking crisis. BIS Quarterly Review, 43-54.

Bussiere, M., \& Fratzscher, M. (2006). Towards a new early warning system of financial crises. Journal of International Money and Finance, 25(6), 953-973.

Cecchetti, S. G., Alfonso, F., \& Krause, S. (2006). Has monetary policy become more efficient? A cross country analysis. Economic Journal, 116(511), 408-433.

Ciccarelli, M., Maddaloni, A., \& Peydro, J. -L. (2010). Trusting the bankers: A new look at the credit channel of monetary policy. ECB Working Paper, 1228.

Crespo-Cuaresma, J., \& Slacik, T. (2009). On the determinants of currency crisis: The role of model uncertainty. Journal of Macroeconomics, 31, 621-632.

Dell'Ariccia, G., Detragiache, E., \& Rajan, R. (2008). The real effect of banking crises. CEPR Discussion $\mathrm{Pa}$ per, 5088, 89-138.

Demirgüç-Kunt, A., \& Detragiache, E. (1998). The determinants of banking crises in developing and developed countries. IMF Staff Papers, 45(1), 81-109.

Demirgüç-Kunt, A., \& Detragiache, E. (2005). Cross-country empirical studies of systemic bank distress: A survey. IMF Working Paper, 5(96).

Frankel, J. A., \& Rose, A. K. (1996). Currency crashes in emerging markets: An empirical treatment. Journal of International Economics, 41(3-4), 351-366.

Frankel, J. A., \& Saravelos, G. (2012). Can leading indicators assess country vulnerability? Evidence from the 2008-2009 global financial crisis. Journal of International Economics, 87(2), 216-231.

Kaminsky, G. L., \& Reinhart, C. M. (1999). The twin crises: The causes of banking and balance-of-pay- 


\section{Analysis of Indonesia Business Cycle through Composite Leading Indicator Data Processing for Banking Industry Annisa Wahyuningsih, Riwi Sumantyo}

ments problems. The American Economic Review, 89(3), 473-500.

Kibritcioglu, B., Kose, B., \& Ugur, G. (1999). A leading indicators approach to the predictability of currency crises: The cases of Turkey. Hazine Dergisi, Sayi Working Paper, 1998(12), 1-31.

Kusuma, I. G. P. W., Surjaningsih, N., \& Siswanto, B. (2004). Leading indikator investasi Indonesia dengan metode OECD. Bulletin of Monetary Economics and Banking Journal, 6(4), 13-41.

Levy-Yeyati, E. L., \& Panizza, U. (2011). The elusive costs of sovereign defaults. Journal of Development Economics, 94(1), 1-150.

Mankiw, G. N. (2000). Teori makroekonomi. Edisi Keempat. Jakarta: Erlangga.
Mody, A., \& Sandri, D. (2012). The eurozone crisis: How sovereigns came to be joined at the hip. Economic Policy, 27(70), 199-230.

Nilsson, R., \& Brunet, O. (2005). Composite leading indicators for major OECD non-economies countries: Brazil, China, India, Indonesia, Russian Federation, South Africa. Journal of Banking $\mathcal{E}$ Finance, $34(9)$, 2255-2264.

Reinhart, C. M., \& Rogoff, K. S. (2011). From financial crash to debt crisis. American Economic Review, American Economic Association, 101(5), 1676-1706.

Setiana, M. (2006). Analisis leading indicator untuk business cycle Indonesia. Tesis. Fakultas Ekonomi dan Manajemen Institut Pertanian Bogor.

Zhang, W., \& Zhuang, J. (2002). Leading indicators of business cycles in Malaysia and the Philippines. ERD Working Paper, 32. 